\title{
A NEW GALL-FORMING BARNACLE IMBEDDED IN THE BARK OF A GORGONACEAN COLONY (ACASTA GREGARIA N. SP.)
}

\author{
AUTHOR(S): \\ Utinomi, Huzio
}

CITATION:

Utinomi, Huzio. A NEW GALL-FORMING BARNACLE IMBEDDED IN THE BARK OF A GORGONACEAN COLONY (ACASTA GREGARIA N. SP.). PUBLICATIONS OF THE SETO MARINE BIOLOGICAL LABORATORY 1959, 7(3): 313-318

\section{ISSUE DATE:}

1959-12-20

URL:

http://hdl.handle.net/2433/174637

RIGHT: 


\title{
A NEW GALL-FORMING BARNACLE IMBEDDED IN THE BARK OF A GORGONACEAN COLONY (ACASTA GREGARIA N. SP.) ${ }^{1)}$
}

\author{
Huzio UTINOMI \\ Seto Marine Biological Laboratory, Sirahama
}

With Plate $X X V$ and 2 Text-figures

As was reviewed by me (HIRo, 1937b, p. 449), the cirriped genus Acasta inhabits sponges or octocorals semiparasitically and a number of species are known in the Indo.West Pacific waters. Of these, several ones are hitherto known living in the coenenchymes of octocorals either invariably or occasionally.

As imbedded in the coenenchyme of Alcyonacean group, the following 3 species are hitherto known:

1) Acasta sculpturata Broch (BROCH, 1931, p. 101)

Java Sea. Host name not given.

2) Acasta echinata Hiro (Hiro, 1937 a, p. 70 ; ВROCH, 1947, p. 23 ; Utinomi, 1949, p. 32)

Kyusyu (Tomioka) and Indochinese coast (Condor Is.). Host:

Dendronephthya.

3) Acasta alcyonicola Utinomi (Utinomi, 1953, p. 142)

Honsyu (Kusimoto and Tanabe Bay). Host: Nephthea crassa KÜKENTHAL ${ }^{2)}$.

As imbedded in the bark of the Gorgonacean group, the following 3 species are hitherto known :

4) Acasta purpurata DARWIN (DARWIN, 1854, p. 318)

Sumatra and Philippine Archipelago. Host: Isis.

5) Acasta hirsuta BROCH (BROCH, 1916, p. 10; ВROCH, 1931, p. 96)

West Australia (Cape Jaubert) and Malay Archipelago (Amboina

Bay). Host: Euplexaura.

6) Acasta spinitergum BROCH (BROCH, 1931, p. 112)

Malay Archipelago (off Samalona, Makasser and Java Sea).

Host name not given.

1) Contributions from the Seto Marine Biological Laboratory, No. 337.

2) Originally mentioned as "Capnella and Nephthea".

Publ. Seto Mar. Biol. Lab., VII (3), 1959. (Article 19) 
Recently through the courtesy of Mr. Torao YамAmoto, I have had an opportunity to examine a new member referable to this group, as describing in the following text.

I am greatly indebted to Mr. Torao Yамамото for placing the specimens of barnacles and their host coral at my disposal and also to Dr. Isamu YAmazI of our Laboratory for preparing a photograph of an Acasta-carrying gorgonacean colony.

\section{Acasta gregaria sp. nov.}

(Figs. 1 and 2)

Occurrence: Tanabe Bay, Prov. Kii, Japan. Depth unknown. April 3, 1959. T. Yамамото leg.

Material: Preserved in the collections of the Seto Marine Biological Laboratory, as designated Type 176a (holotype), 176 b (paratypes) and 177 (paratypes).

Description: The specimens are abundantly imbedded wholly in the bark of a flabellate colony of the genus Euplexaura. The host colony is allied to E. anastomosans BRUNDIN in the spiculation, but may be an undescribed species.

The barnacles are gregarious all round the branches of Euplexaura, forming polypiferous "galls" (see PLATE XXV). Owing to the very intimate adherence to the tough spiculiferous coenenchymes and the brittleness of shell plates, it is impossible to detach intact specimens of the cirriped.

The whole shell detached is ivory white, with pinkish hue upwards. It is, when complete, sub-globular in shape and oval in outline of the basal cup.

The basal cup is moderately shallow, but not prolonged in the carino-rostral axis and not directly attached to the horny axis of the host gorgonid. It is rather fragile and exhibits a structure of concentric, alternating hyaline and less transparent white rings. No canaliculation is found at all The upper edge is generally smooth, so that the basal cup may be easily detachable from the compartments.

The largest specimen measures about $6 \mathrm{~mm}$ in carino-rostral diameter. The total height slightly exceeds the carino-rostral diameter.

The compartments are also thin and weakly connected with one another by radii and alae. On the external surface the parietes are furnished with many downturned calcareous spines. These spines are irregularly arranged all over the surface. They are generally short, bluntly tipped and empty internally. The internal side of the parietes is furnished with prominent but narrow longitudinal ribs below the sheath which is longer than the lower wall.

The radii and alae are broad and have straight upper margin very oblique to the basal margin of the parietes.

The rostrum is the widest of all compartments, nearly erect; its basal width is about two-thirds of its own length.

The carinal latus is very narrow, about one-seventh as wide as the carina. The 
carina is about three-fifths as wide as the rostrum and about two-thirds of its own length.

The scutum is rather thick, higher than wide, and has strongly crenated and beaded growth-ridges as crossed by close radiating (longitudinal) furrows. On the internal surface a broad and deep pit for the adductor muscle is distinctly indicated.
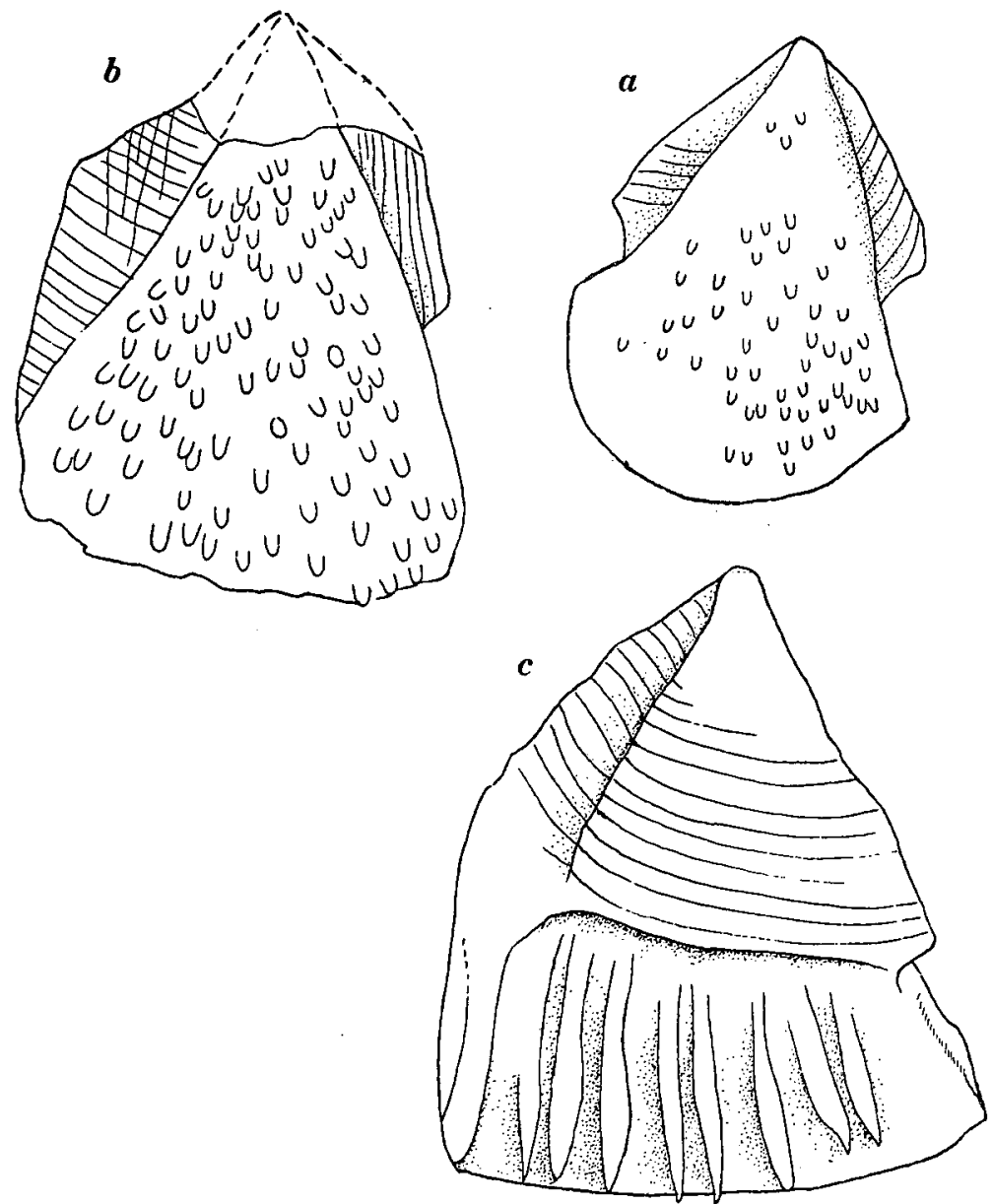

Fig. 1. Acasta gregaria n. sp.

$a$ External side of carina, $b$ external side of lateral compartment, $c$ internal side of lateral compartment. All $\times 18$.

It is clearly separated from the articular ridge by a slight longitudinal furrow extending down to a shallow depression for the lateral depressor muscle. The articular furrow is wide and deep.

The tergum is rather thin and a little longer than wide. The apex is not beaked. The upper (carinal) margin is nearly straight and subequal to the scutal margin in 
length. The carinobasal corner is angular, forming an angle of about $70^{\circ}$. The spur is short and wide, about one-half of the basal margin of the valve, and truncated at the end. A broad but shallow spur-fasciole runs from the apex to the end of the spur. On the external surface, the growth-ridges are generally smooth but slightly crenated towards the carinal margin. The internal surface is flattened, generally

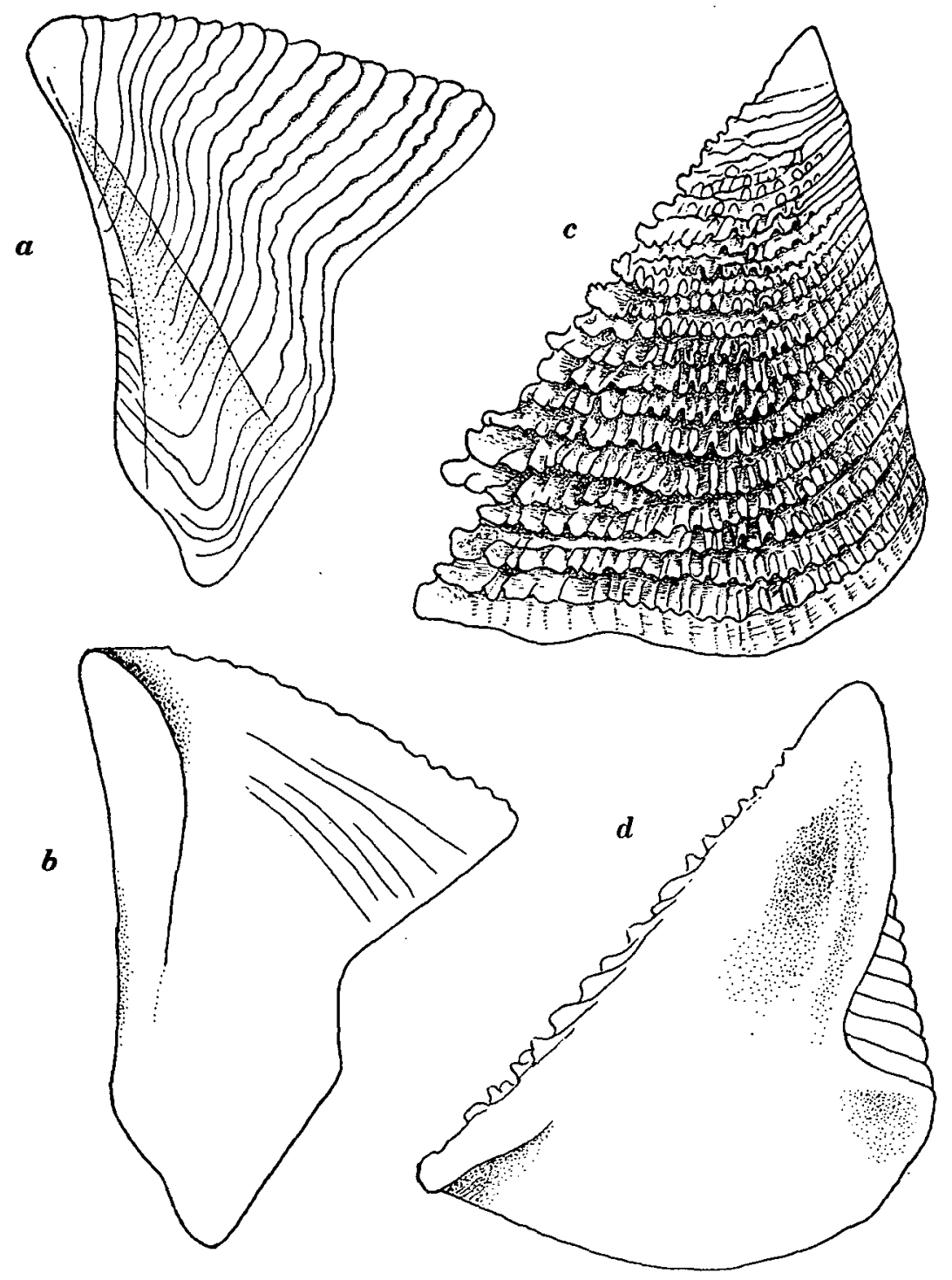

Fig. 2. Acasta gregaria n. sp.

$a$ External side of tergum, $b$ internal side of tergum, $c$ external side of scutum, $d$ internal side of scutum. All $\times 33$. 
smooth, but a few long crests for the depressor muscles (6-7 in number) are feebly indicated.

The internal body could not be studied as all specimens were dried before examination.

Remarks: The present species is doubtless nearly allied to Acasta hirsuta BRocH (1916) by its general appearance and its habitat as occurring in the bark of Euplexaura colony. It is also allied to A. spinitergum Broch (1931) and Balanus (Conopea) fragilis BROCH (1931) in the structure of the opercular valves. But, it may be distinct from these allies as indicating by the cup-formed basis, the more strongly cancellated scutum and the non-beaked tergum, even if the internal anatomy is not examined.

\section{LITERATURE}

Broch, Hj. 1916. Results of Dr. E. Mjöbergs Swedish Scientific Expeditions to Australia 191013. VIII. Cirripedien. Kungl. Svenska Vetenskapsakad. Handlingar, Bd. 52, no. 8, pp. 1-16, Taf. 1-2.

- 1931. Papers from Dr. Th. Mortensen's Pacific Expedition 1914-16. LVI. Indomalayan Cirripedia. Vidensk. Medd. fra Dansk naturh. Foren., Bd. 91, pp. 1-146.

- 1947. Cirripedes from Indochinese shallow-waters. Avhandl. utgitt av Det Norske Vidensk.-Akad. i Oslo, I. Mat.-Naturv. K1., 1947, no. 7, pp. 1-32.

DARwin, Ch. 1854. A monograph on the sub-class Cirripedia. II. The Balanidae, Verrucidae etc. Ray Society, London.

Hiro, F. 1937a. A new barnacle, Acasta echinata n. sp., imbedded in the stalk of an alcyo. narian from southern Japan. Zool. Mag. Tokyo, vol. 49, no. 2, pp. 70-71.

- 1937b. Studies on Cirripedian fauna of Japan. II. Cirripeds found in the vicinity of the Seto Marine Biological Laboratory. Mem. Coll. Sci., Kyoto Imp. Univ., Ser. B, vol. 12, no. 3, pp. 385-478.

Utinomi, H. (formerly Hiro, F.) 1949. Studies on the Cirripedian fauna of Japan. VI. Cirripeds from Kyusyu and Ryukyu Islands. Publ. Seto Mar. Biol. Lab., vol. 1, no. 2, pp. 19-37.

1953. On two interesting species of epizoic barnacle Acasta from Japan. Mem. Coll. Sci., Univ. Kyoto, Ser. B, vol. 20, no. 3, pp. 139-144. 


\section{EXPLANATION OF PLATE XXY}

Photograph of a flabellate colony of Euplexaura sp. parasitized by a number of the barnacle Acasta gregaria n. sp. Natural size. 
Publ. Seto Mar. Biol. Lab., VII, 3 (1959)

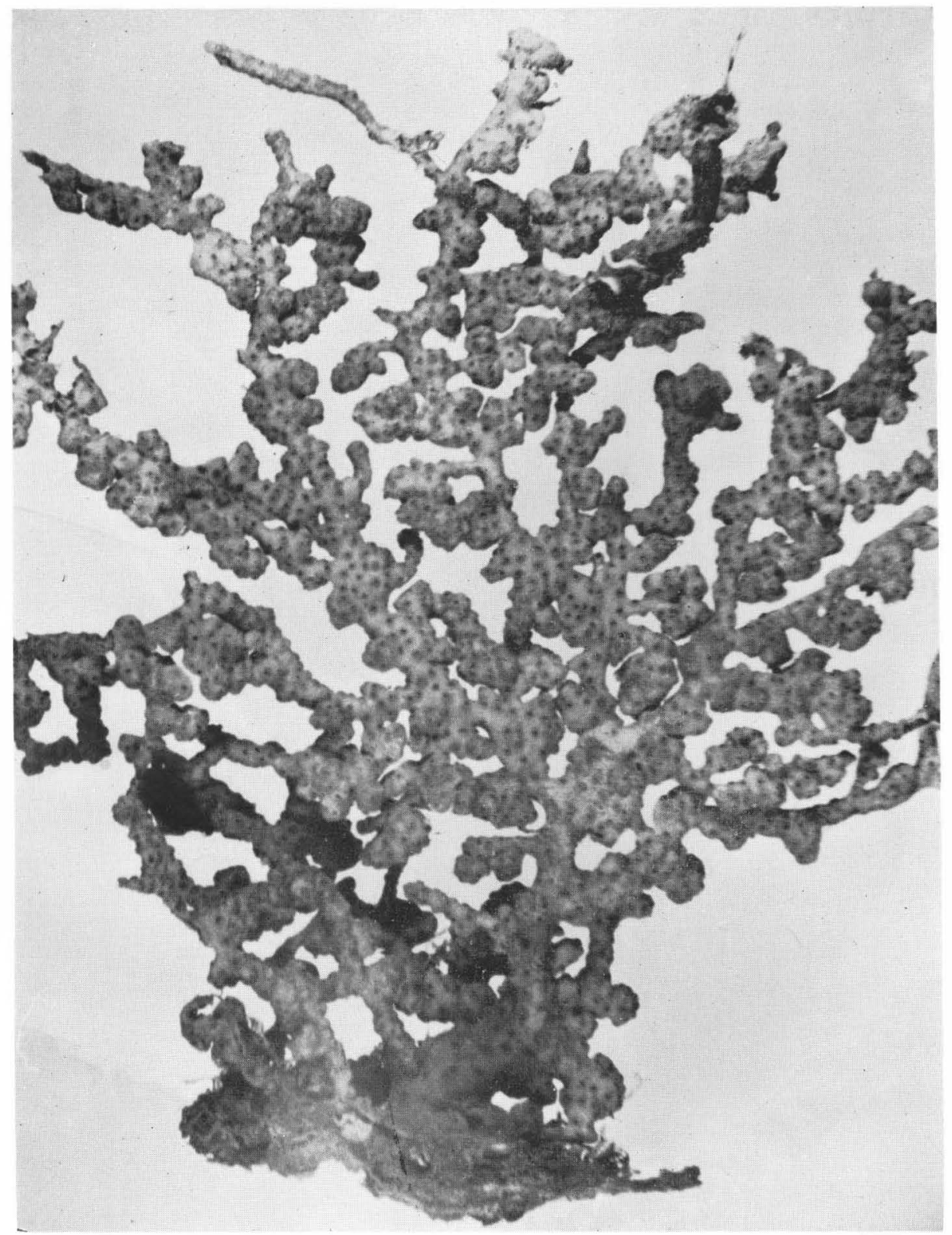

H. Utinomi : A New Gall-forming Barnacle (Acasta gregaria n. sp.). 